\title{
Capillary Enzyme Immunoassay for Rapid Detection of Herpes Simplex Virus in Clinical Specimens
}

\author{
ISABEL C. SHEKARCHI, ${ }^{1 *}$ DAVID A. FUCCILLO,${ }^{1}$ ROBERT STROUSE,${ }^{1}$ AND JOHN L. SEVER ${ }^{2}$ \\ Microbiological Associates, Inc., Bethesda, Maryland $20816,{ }^{1}$ and Infectious Diseases Branch, National Institute of \\ Neurological and Communicative Disorders and Stroke, Bethesda, Maryland 20892 2
}

Received 1 August 1986/Accepted 27 October 1986

\begin{abstract}
Capillary enzyme immunosorbent assay (CapELISA) is a modification of the standard enzyme immunosorbent assay which permits rapid detection of viral antigens in clinical specimens. The capillary tube format provides a very large reactive surface relative to the sample size. The close proximity of antigen to antibody in the tube optimizes the reaction, resulting in increased sensitivity and shorter incubation requirements. Sensitivity is further enhanced by use of a biotin-avidin enzyme detector system and a fluorogenic rather than a colorigenic substrate. The assay is performed at ambient temperature and requires less than $\mathbf{2} \mathrm{h}$. It is read with an inexpensive hand-held black light. Data for the use of CapELISA for the detection of herpes simplex virus in clinical specimens are presented. The results show $\geq 85 \%$ sensitivity and $100 \%$ specificity when compared with tissue culture tests on the same samples. This new system should be advantageous for the diagnosis, treatment, and management of patients with herpesvirus infections and for the prevention of neonatal herpes acquired by passage of the fetus through an infected birth canal.
\end{abstract}

The enzyme immunosorbent assay (EIA) is a widely used and accepted method for detecting antibodies to many viral antigens. In its usual format, however, it is less effective as a method for detecting viral antigens in clinical specimens, especially when a relatively small amount of antigen is present. Recent methods to amplify sensitivity of the EIA have included increasing the amount of reactive surface and of contact between reactants of interest, e.g., beads (7), nitrocellulose disks (5), capillaries (2); improving the bonding and strength of the detector reagent, e.g., biotin-avidin $(3,4)$; and increasing the speed and sensitivity of the substrate, e.g., fluorescent and chemiluminescent substrates (9). A method which incorporates a number of these modifications of the standard EIA and which permits rapid detection of viral antigens in clinical specimens has been developed at Microbiological Associates, Inc. It employs a plastic capillary as the solid phase, a biotin-avidin detection system, and a fluorescent substrate and is called CapELISA.

The plastic capillary provides a very large reactive surface relative to sample size, and the forced close proximity of antigen to antibody optimizes the reaction between the two entities. Thus, increased sensitivity and shorter incubation times can be achieved. Recent use of the high avidity of avidin for biotin and the capacity of avidin to bind four molecules of biotin has made it possible to amplify the detector signal of the EIA $(4,6)$. Fluorescent substrates have been shown to be 100 to 1,000 times more sensitive than colorigenic substrates (9).

The assay is performed at ambient temperatures and requires less than $2 \mathrm{~h}$. It is read with an inexpensive hand-held black light. CapELISA has been developed for use in detecting bacterial, fungal, and viral antigens. Other assays will be presented in later papers. This paper deals with the application of CapELISA to the detection of herpes simplex virus (HSV) in clinical specimens.

(This work was presented at the March 1986 meeting of the American Society for Microbiology, Washington, D.C.)

\footnotetext{
* Corresponding author.
}

\section{MATERIALS AND METHODS}

Avidin-alkaline phosphatase conjugate. Avidin-alkaline phosphatase conjugate is commercially available (Vector Laboratories, Burlingame, Calif.; Sigma Chemical Co., St. Louis, Mo.) or can be prepared by the method of Avrameas (8). Briefly, add $2 \mathrm{mg}$ of egg avidin in $1 \mathrm{ml}$ of Tris-buffered saline (TBS) to $5 \mathrm{mg}$ of alkaline phosphatase (4502; Sigma Chemical Co.) and dialyze against TBS overnight. Add electron microscopy grade glutaraldehyde to a final concentration of $0.2 \%$. Incubate with gentle shaking for $2 \mathrm{~h}$ at room temperature. Dialyze at $4^{\circ} \mathrm{C}$ against several changes of TBS (pH 7.5). Add $1 \%$ bovine serum albumin and store at $4^{\circ} \mathrm{C}$. TBS ( $\mathrm{pH}$ 7.5) contains: Trizma hydrochloride, $6.35 \mathrm{~g}$; Trizma base, $1.18 \mathrm{~g}$; sodium chloride, $8 \mathrm{~g}$; and $\mathrm{H}_{2} \mathrm{O}$, to 1 liter.

Biotin-labeled anti-HSV. Activated biotin ester with a seven-atom spacer arm (Enzotin-Enzo Biochem, Inc., New York, N.Y.) was bound to antiherpesvirus immunoglobulin $\mathrm{G}$ by the method of Guesden et al. (4). A 1-ml portion of rabbit anti-HSV immunoglobulin G (Dako B114; Accurate Chemicals, Westbury, N.Y.) made up to $4 \mathrm{mg}$ of protein per $\mathrm{ml}$ is dialyzed overnight against $0.1 \mathrm{M}$ sodium carbonate. Then add $120 \mu \mathrm{l}$ of Enzotin biotinylating reagent $(4 \mathrm{mg}$ in 1 $\mathrm{ml}$ of dimethylformamide). Incubate for $4 \mathrm{~h}$ at room temperature (RT) or overnight at $4^{\circ} \mathrm{C}$. Dialyze extensively against TBS with $0.02 \%$ sodium azide $\left(\mathrm{NaN}_{3}\right)$.

HSV tissue culture antigen. Stocks of HSV type 1, MacIntyre strain VR3, were grown on MA111 to 4+ cytopathic effect. The cells were scraped from the surface, pooled, frozen at $-70^{\circ} \mathrm{C}$, and thawed once. Cell debris and virus were removed by centrifugation (Spinco) at $2,500 \times g$ for $90 \mathrm{~min}$, suspended in glycine hydroxide, frozen and thawed three times, and centrifuged at $2,000 \times g$ for $10 \mathrm{~min}$. The supernatant was saved as antigen. Protein content was 1 $\mathrm{mg} / \mathrm{ml}$. This antigen was aliquoted and stored at $-70^{\circ} \mathrm{C}$. Uninoculated tissue culture treated in the same manner served as one control.

Solid-phase carrier. A polypropylene capillary $(150-\mathrm{mm}$ inner diameter, $250-\mathrm{mm}$ outer diameter, $11.5-\mathrm{cm}$ length) 


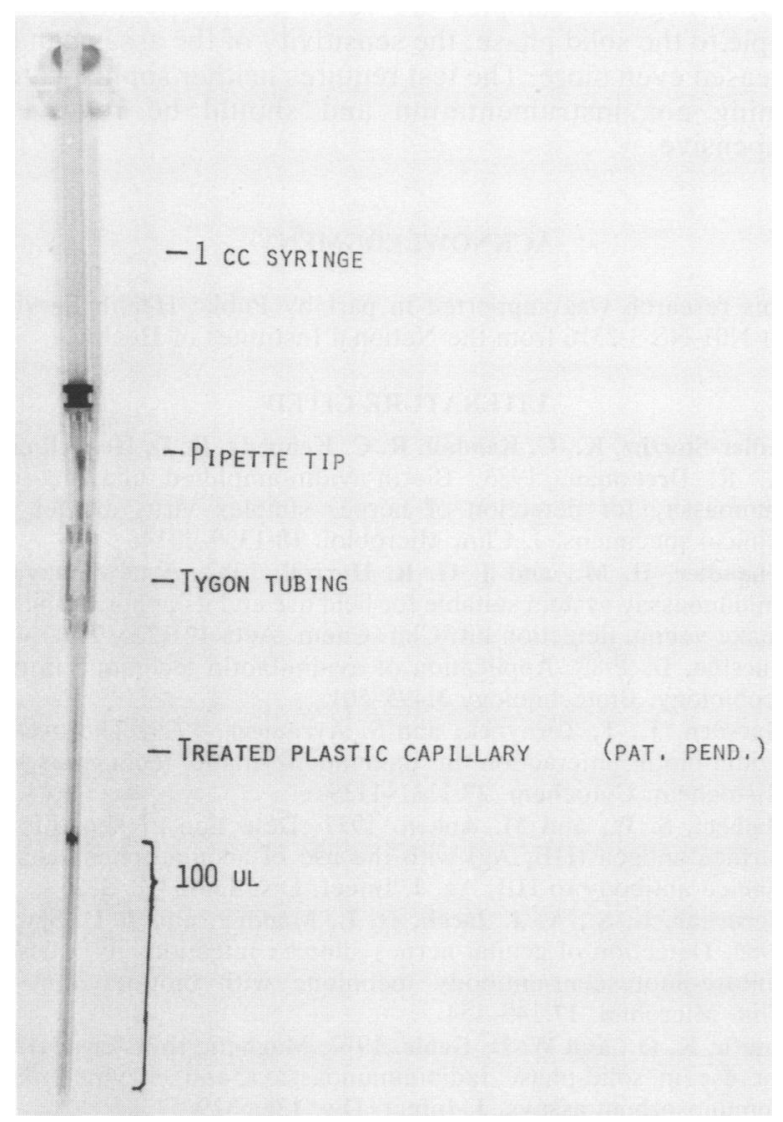

FIG. 1. Microbiological Associates, Inc., capillary assay device.

from Microbiological Associates, Inc., is used as the solid phase. A proprietary (patent pending) treatment of the inside of the capillary before sensitization assures a uniform and reproducible reaction surface.

The capillary tube is attached to a $1-\mathrm{cm}^{3}$ syringe with a 1 -in. $(2.5-\mathrm{cm})$ piece of Tygon tubing and a plastic disposable pipette tip. The top and bottom of the pipette tip are cut so that the capillary and syringe fit snugly together. The tube is marked to indicate a $100-\mu l$ volume (Fig. 1).

The pretreated capillary is sensitized by adding $100 \mu \mathrm{l}$ of capture antibody, in this case rabbit anti-HSV antibody (Dako B114), diluted 1:100 in coating buffer (pH 9.6) (C buffer: sodium carbonate, $1.59 \mathrm{~g}$; sodium bicarbonate, 2.93 $\mathrm{g}$; sodium azide, $0.2 \mathrm{~g} ; \mathrm{H}_{2} \mathrm{O}$ to make 1 liter). The tubes are incubated in a moist chamber at $37^{\circ} \mathrm{C}$ for $90 \mathrm{~min}$ or overnight at $4^{\circ} \mathrm{C}$ and then washed. Washing the capillary is best accomplished with a Repipet jr. dispenser (Labindustries, Inc., Berkeley, Calif.). The syringe is removed from the capillary assembly, and $1 \mathrm{ml}$ of TBS containing $0.05 \%$ Tween 20 is passed through the tube in one direction. Only the inside of the tube is washed; therefore, it is necessary to carefully wipe any reactants away from the outside of the tube. To block unused sites and to reduce nonspecific reactions, $100 \mu \mathrm{l}$ of $\mathrm{C}$ buffer containing $1 \%$ normal rabbit serum, $1 \%$ normal swine serum, and $0.2 \%$ normal bovine serum albumin fat free (Sigma A0281) is drawn into the tube and incubated at RT for $15 \mathrm{~min}$. Capillaries are then washed as above and are ready for the assay. Sensitized capillaries, sealed in a plastic bag, have been stored at $-70^{\circ} \mathrm{C}$ for several weeks without loss in activity.
TABLE 1. Comparison of CapELISA with tissue culture for detection of HSV antigen in clinical samples ${ }^{a}$

\begin{tabular}{lcc}
\hline \multirow{2}{*}{ CapELISA result } & \multicolumn{2}{c}{ No. of samples that were tissue culture: } \\
\cline { 2 - 3 } & Positive & Negative \\
\hline Positive & 20 & 0 \\
Negative & 4 & 66 \\
\hline
\end{tabular}

${ }^{a}$ Sensitivity of detection, $85 \%$; specificity, $100 \%$.

Assay procedure. (i) Draw $100 \mu$ l of tissue culture-grown HSV $(1: 1,000)$, as positive control, clinical sample, or sample collection medium, as negative control, diluted in sample diluent (TBS with $1 \%$ normal rabbit serum, $1 \%$ normal swine serum, and $0.2 \%$ bovine serum albumin) into the sensitized tube and incubate at RT for $30 \mathrm{~min}$. Wash the capillary as above.

(ii) Draw $100 \mu$ l of biotin-labeled rabbit anti-HSV diluted 1:100 in sample diluent into the tube and incubate at RT for $15 \mathrm{~min}$. Wash as above.

(iii) Draw $100 \mu \mathrm{l}$ of avidin-alkaline phosphatase diluted 1:400 in sample diluent into the tube and incubate at RT for $15 \mathrm{~min}$. Wash as above.

(iv) Draw $100 \mu \mathrm{l}$ of $0.025 \mathrm{M}$ 4-methylumbelliferyl phosphate in AMP working buffer (Sigma 960-7) with $0.01 \%$ $\mathrm{MgCl}_{2}$ into the tube.

(v) Read with a hand-held, long-wave black light, (e.g., UV Products, San Gabriel, Calif.) after $\leq 15 \mathrm{~min}$. Controls for minimal nonspecific background allow easy distinction between fluorescent and nonfluorescent samples.

Parameters of the HSV antigen assay were first determined with a culture-grown virus stain (HSV type 1, MacIntyre VR3) and control antigen. The clinical samples tested were part of a study of herpesvirus in pregnant women and attendees at a maternity center and were supplied by Lata Nerurkar, National Institutes of Health. These samples were collected by rubbing lesions in the genital or vaginal area with cotton swabs. The swabs were placed in $3 \mathrm{ml}$ of Eagle minimum essential medium containing streptomycin, penicillin, and nystatin (collection medium) and frozen at $-70^{\circ} \mathrm{C}$. Standard tissue culture technique in tube cultures was used by L. Nerurkar to determine which samples were positive. A $200-\mu l$ portion from the clinical sample was added to human foreskin fibroblast monolayers (Flow 7000). After absorption overnight, fresh Eagle minimal essential medium with $2 \%$ fetal calf serum was added. The cultures were incubated in a $5 \% \mathrm{CO}_{2}$ incubator for 7 to 10 days. They were checked daily for typical cytopathic effect for 5 days and every other day thereafter. For the CapELISA, specimens were tested directly from the collection medium or diluted 1:2 in TBS. Controls consisted of tissue culturegrown virus $(1: 1,000)$ and sample collection medium diluted in TBS.

\section{RESULTS}

With tissue culture-grown antigen, CapELISA could detect $\geq 10 \mathrm{ng}$ of antigen protein. Of 90 clinical specimens included in the study, 24 were positive by tissue culture. The CapELISA detected 20 positive specimens in this group for a sensitivity of $85 \%$. Three of the four false-negative samples were CapELISA positive when the sensitized capillary was exposed to two or three portions of the clinical sample for a sensitivity of $95.4 \%$. All 66 samples negative by tissue culture were negative by CapELISA for a specificity of $100 \%$. These results are presented in Table 1. 
Because the test reagents are very sensitive, great care must be taken to ensure minimal background reading. Careful washing and wiping of the tips after each step will greatly reduce background.

The fluorescent substrate is extremely sensitive, and any contamination in the substrate buffer will be reflected in the test. The substrate should be prepared fresh each day and should be protected from light. For use, it is measured into clean microtiter wells so that no cross contamination occurs by dipping the capillary into the reagent.

\section{DISCUSSION}

The modifications of EIA incorporated in CapELISA resulted in a simple, sensitive, and rapid assay suitable for use in detecting herpesviral antigen in clinical specimens in under $2 \mathrm{~h}$. The plastic capillary can be treated to bind proteins consistently and is sturdy enough to be fieldworthy. It provides a large reactive surface relative to sample volume, and the forced close proximity of antigen to antibody optimizes the reaction between them. It also reduces the dependence on temperature and time. The detector system is more sensitive owing to the avidity of the avidin-biotin bond and to the potential for amplification through use of an avidin-biotin complex. The sensitivity is further increased by use of a fluorescent rather than a colorigenic substrate. The fluorescence develops rapidly and is readily visible when viewed with an inexpensive hand-held long-wave black light.

The use of biotin-avidin amplification in EIAs for rapid detection of HSV antigen in clinical samples has been shown to be useful $(1,6)$. These assays performed in microtiter plates require about $4 \mathrm{~h}$, and Nerurkar et al. (6) using streptavidin reported a sensitivity of $95.6 \%$ and a specificity of $91.4 \%$ compared with standard tissue culture methods. The plate assay is well suited to large-scale assays in which many samples are to be tested. In this study we developed a method to simplify the methodology and increase sensitivity by using the capillary tube format for the test reaction. Thus, CapELISA is better suited to small sample numbers and situations in which results within $2 \mathrm{~h}$ are advantageous.
Also, if negative samples are rerun by multiexposure of sample to the solid phase, the sensitivity of the assay can be increased even more. The test requires neither sophisticated training nor instrumentation and should be relatively inexpensive.

\section{ACKNOWLEDGMENT}

This research was supported in part by Public Health Service grant N01-NS-3-2316 from the National Institutes of Health.

\section{LITERATURE CITED}

1. Adler-Storthz, K., C. Kendall, R. C. Kennedy, R. D. Henkel, and G. R. Dreesman. 1983. Biotin-avidin-amplified enzyme immunoassay for detection of herpes simplex virus antigen in clinical specimens. J. Clin. Microbiol. 18:1329-1334.

2. Chandler, H. M., and J. G. R. Hurrell. 1982. A new enzyme immunoassay system suitable for field use and its application in a snake venom detection kit. Clin. Chem. Acta 121:225-230.

3. Fuccillo, D. 1985. Application of avidin-biotin technique in microbiology. Biotechnology 3:495-501.

4. Guesden, J., T. Ternynck, and S. Avrameas. 1979. The use of avidin-biotin interaction in immunoenzymatic techniques. J. Histochem. Cytochem. 27:1131-1139.

5. Halbert, S. P., and M. Anken. 1977. Detection of hepatitis B surface antigen $\left(\mathrm{HB}_{\mathrm{s}} \mathrm{Ag}\right)$ with the use of alkaline phosphatase labeled antibody to $\mathrm{HB}_{\mathrm{s}} \mathrm{Ag}$. J. Infect. Dis. 136:S318-S323.

6. Nerurkar, L. S., A. J. Jacob, D. L. Madden, and J. L. Sever. 1983. Detection of genital herpes simplex infections by a tissue culture-fluorescent-antibody technique with biotin-avidin. J. Clin. Microbiol. 17:149-154.

7. Smith, K. O., and W. D. Gehle. 1977. Magnetic transfer devices for use in solid-phase radioimmunoassays and enzyme-linked immunosorbent assays. J. Infect. Dis. 136:5329-5336.

8. Voller, A., D. Bidwell, and A. Bartlett. 1976. Microplate enzyme immunoassays for immunodiagnosis of viral infections, $p$. 500-510. In N. R. Rose and H. Friedman (ed.), Manual of clinical immunology. American Society for Microbiology, Washington, D.C.

9. Yolken, R. H., and F. J. Leister. 1982. Comparison of fluorescent and colorigenic substrates for enzyme immunoassays. J. Clin. Microbiol. 15:757-760. 